\title{
Energy Optimization and Environmental Impact of an Office Building at Biskra City, Algeria: Life Cycle Assessment, Applied to the Building Envelope in Hot and Dry Climate
}

\author{
Azzedine Dakhia $^{1^{*}}$, Noureddine Zemmouri ${ }^{2}$ \\ ${ }^{1}$ Département d'Architecture, Université Mohamed Khider Biskra, BP145 RP, Biskra 07000, Algeria \\ ${ }^{2}$ Laboratoire de Conception et Modélisation des Formes Architecturales LACOMOFA, Université Mohamed Khider de Biskra, \\ BP145 RP, Biskra 07000, Algeria
}

Corresponding Author Email: az.dakhia@univ-biskra.dz

https://doi.org/10.18280/ijsdp.160208

Received: 27 November 2019

Accepted: 14 January 2021

\section{Keywords:}

building environmental impact, life cycle assessment (LCA), energy efficiency, building envelope, recycled materials, thermal insulation system, arid region

\begin{abstract}
This work assesses the environmental impact generated by an office building in arid region throughout its life cycle (cradle to grave), by means of a Life Cycle Assessment (LCA). This study focuses on a comparison of different external wall systems that are conventionally used in building. With recycled materials and thermal insulation system, it's possible to reduce demand of energy consumption, evaluate their environmental indicators impacts, and also reduce them, throughout the building life cycle. In doing so, this work can contribute not only to control energy, long-term economic growth, but also to address pressing social issues, and mainly environmental impacts. We use an environmental analysis with a thermal dynamic simulation, to test the hypothesis on a data base of hot and dry climate of Biskra city. The last part consists of a technical approach, indicating the economy is the use of ecological and recycled materials. The results of this study show that the exterior insulation system, obtained the best environmental scores, being 30\% less than the interior insulation system and 50\% less than the distributed insulation system. Also, recycled materials save energy in their manufacture, and building energy consumption for its use and have a reduced building impact on the environment throughout its life cycle (cradle to grave). This work shows how LCA application is not only feasible, but recommended because it is a decision support tool in the search for sustainability and make use of recycled materials.
\end{abstract}

\section{INTRODUCTION}

"Development that meets the needs of the present without compromising the ability of future generations to meet their own needs", it's the definition of 'Sustainable Development' adopted by the international community, in his report Our common future published by the World Commission on Environment and Development (WCED) [1]. The Brundtland Report developed guiding principles for sustainable development as it is generally understood today. It is an approach applied to decision-making, requiring diverse and united actions in the various sectors of the economy, environment, health, agriculture, construction and building, etc. Building is the most energy-intensive sector in the world, exceeding $45 \%$ of total energy consumption, with $50 \%$ of total exploited natural resources [2]. The key issues are therefore to reduce energy consumption in this crucial sector, as well as its environmental impact. Emissions of building-related pollutants are also high; both in air (30\% of total emissions of $\mathrm{CO}^{2}$, greenhouse gases), and in water with more than $40 \%$ of product waste [3]. Then, it's important to improve the energy performance of buildings, and to have multi-criteria tools, sufficiently reliable, to highlight the sources of environmental impacts (greenhouse effect, eutrophication, water consumption...), throughout life cycle building)" cradle to grave" [4].
This paper exposes, a life cycle analysis LCA carried about an office building, the Urban Agency of Biskra (Algeria). Our objective is to conduct an accurate quantitative assessment of the environmental impact of this building) [5], throughout its life cycle, allowing designers to make the most consistent choice (green building materials, building systems, HVAC system and energy, etc.) in relation to their sustainable building objectives [6].

The oil crisis, the significant increase in the prices of fossil fuels, as well as the awareness for certain phenomena affecting the environment such as: global warming, the depletion of some natural resources, and damage to terrestrial and marine ecosystems, have led to a desire to significantly reduce energy consumption related to the use of buildings (Heating, Air Conditioning, Ventilation, and Lighting, etc...) [7, 8]. Also, energy requirements in the building are reduced mainly by good insulation and high performance sealing to attain the BBC low-energy building objective). Additionally, increasing the thermal performance of a building implies both a multiplication of components of its envelope. This becomes a priority consideration in reducing the environmental impacts of the building [9]. This work is part of this line of action, enabling the design of thermally efficient, energy-saving building, and respecting the environment through the use of environmentally friendly materials and recycled materials. 


\section{LIFE CYCLE ANALYSIS METHODOLOGY}

Life Cycle Analysis is a scientifically recognized and standardized methodology used to assess the environmental impacts of a product, or process, from the extraction of raw materials to its end-of-life treatment (landfill, recycling, etc.)" cradle to grave" [10]. Life Cycle Analysis of product is mainly associated with objectives of certification, diagnosis of the existing, evaluation of an existing and frozen situation [5]. However, the life cycle analysis of buildings [11] will be oriented towards objectives of system evolution, analysis of public policy of housing, public buildings, offices, hospitals, schools, etc..., decision aid and environmental impact assessment [12]. It consists at four 04 phases: construction, use, renovations, and end-of-life [13] (Figure 1). The limit of the analysis: from the realization of the building until its end of life through the phases of use and renovations; the demolition consists in allowing the recovery and the recycling of the materials resulting from this operation. it is specified that LCA for our case supports only the building materials from the phase of realization of the building until the end of the life of the latter, and does not take into account the extraction of raw materials and the manufacture of materials and their transport to the construction site.

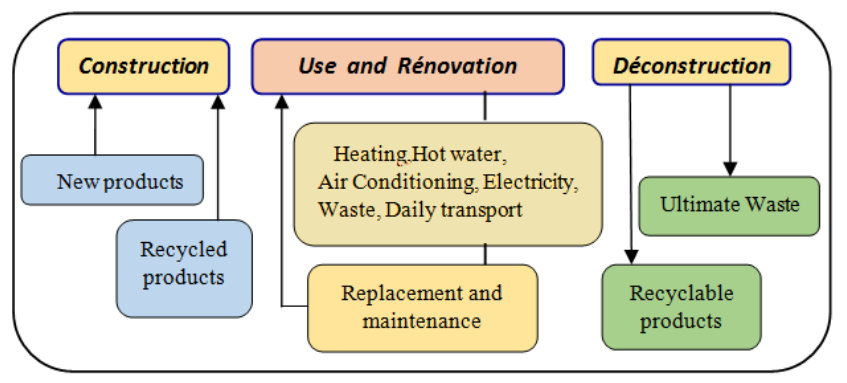

Figure 1. Phases of the life cycle of a building

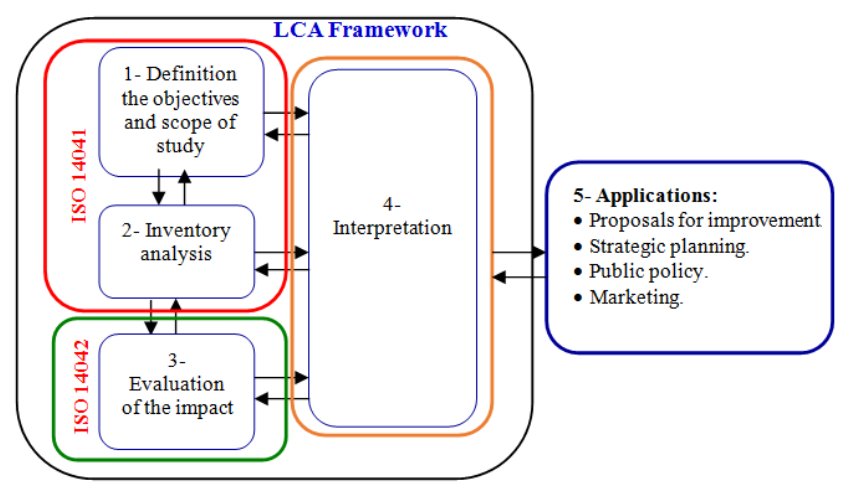

Figure 2. Framework for a life cycle analysis

Also, the results of this life-cycle analysis are leveraged by identifying directions for improvement proposals, strategic planning, public policy, marketing, etc.

The most important challenge of the Life Cycle Analysis approach [14], are: identify, avoid, eliminate the main sources of environmental impacts, where appropriate, to minimize them and to arbitrate the movements of pollution linked to the various alternatives envisaged [15]. The aim of this study is to obtain results from a comparative life cycle analysis [16] between several exterior wall configurations [17], which will: a) Quantify all energy consumption (air conditioning, heating, ventilation and lighting, etc.).

b) Make energy optimization that will determine all environmental impacts during building life cycle.

c) And so assess the building's environmental adaptation in relation to the hot and dry climate context.

This method is based on a 4-step approach (Figure 2).

\section{BISKRA, STUDY CONTEXT}

Our choice of tertiary architecture for energy and environmental studies through a "Life Cycle Analysis LCA of buildings" approach stems from reasons [18]:

a. Office buildings draw, urban silhouette.

b. It is the world's largest energy user, with more than $42 \%$ of total energy consumption in Algeria.

c. Office buildings are also responsible for greenhouse, gas emissions, and other environmental impacts.

Biskra is representative of all Algerian cities, of arid regions with a hot and dry climate. This zone D called the Pre Sahara Zone [19], and whose climate is distinguished by:

1. Maximum temperatures are recorded in summer, July and get to $45.2^{\circ} \mathrm{C}$.

2. Minimum Temperatures are recorded in winter with $2.2^{\circ} \mathrm{C}$ in January.

3. Strong insulation exceeding $3500 \mathrm{~h} /$ year.

4. Intense direct solar radiation up to 900 to $1100 \mathrm{~W} / \mathrm{m}^{2}$.

5. Relative humidity remains low at $27 \%$.
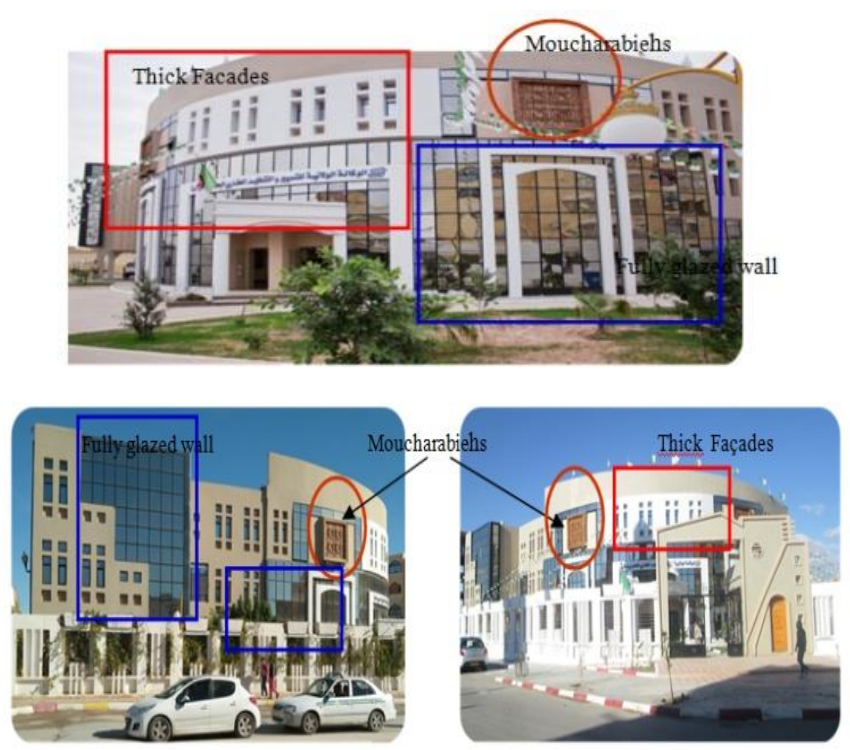

Figure 3. Building, study case

The Urban Agency of Biskra (Algeria) is a new construction, following an architecture competition in 2012. It presents a multiple architectural language using standard constructive materials, and techniques systems (concrete structure, exterior masonry in terracotta bricks, coatings, wood, ceramics, plasters, etc.), and integrating other new elements (bay window, glazed walls). It is representative of all the buildings built in the city of Biskra, and all the Algerian country in recent years, bringing together the different materials, construction systems and techniques as well as for installed and integrated heating and air conditioning energy systems (HVAC). The building's façades (South-East, South-West and West) are not 
in keeping with the guidelines recommended for architecture in an arid region with a hot and dry climate [20] and not equipped with appropriate sun protection devices. Also, the building envelope is very varied, the components of which are (Figure 3): single wall $15 \mathrm{~cm}$, double wall $30 \mathrm{~cm}$ in clay hollow brick with $5 \mathrm{~cm}$ air blade, Moucharabieh with red wooden, glazed wall.

The thermal insulation realized in this building is very basic, limited by a distributed insulation type or sandwich (double wall with a blade of air of $05 \mathrm{~cm}$ ). For the others shell components, no insulation was performed.

\section{SIMULATION}

This This Life Cycle Assessment is an experimental study, takes the form of an informatics simulation. It is conducted using the Comfie-Pleiades dynamic heat behavior simulation software (version 3.6.9.0, 2016) linked to the building environmental impact study software, nova-Equer (version 1.6.9.0, 2016). The programs are available, with a user license and very practical, subscribing to results and decision support guidelines especially for professionals in the building sector. For this study, Ecoinvent is the database used. It's provides well documented process data for thousands of products, helping you make truly informed choices about their environmental impact.

\subsection{Protocol and simulation tools}

As input to the simulation, the Alcyone software defines all the building data (geometry, materials...) and the site data (orientation, neighborhood, environment, close masks) as well as weather data from the city of Biskra, 'meteor norms' (version 7.1.0.0, 2016). The thermal zones of the building, which should have equivalent thermal behavior [21], are then defined.

Also, Comfie-Pleiades are the dynamic thermal simulation DTS software for buildings [22]. Using data on building materials, occupancy scenarios and weather conditions, the software calculates the energy requirements for heating and cooling and lighting of the building for a given period of time (up to one year).

The energy requirements already assessed are exported to Nova-Equer, which is the environmental impact assessment tool for buildings [23]. Other additional input data shall be provided to the software to perform life cycle analysis, such as the energy mix of electricity consumed, waste can be recycled, type of transport, etc...

The first simulation involves intervention at the origin, nature and type of insulation used for the walls of the building envelope (expanded polystyrene, cellulose wadding).

The first criteria for selected insulation are ecological [24]: renewable and recyclable raw materials, little grey energy, and C02 emissions for their manufacture, and low impact on indoor air quality and human health [25]. The second involves intervention on the insulation technique of the building envelope (the distributed, by the exterior or by the interior insulation) (Figure 4).

The study includes:

a) The insulation implementation technique.

b) Thermal quality levels of the building.

c) Energy optimizations.

d) Environmental impacts.
The classification is based on the simulation results for energy performance and environmental impacts (Table 1).

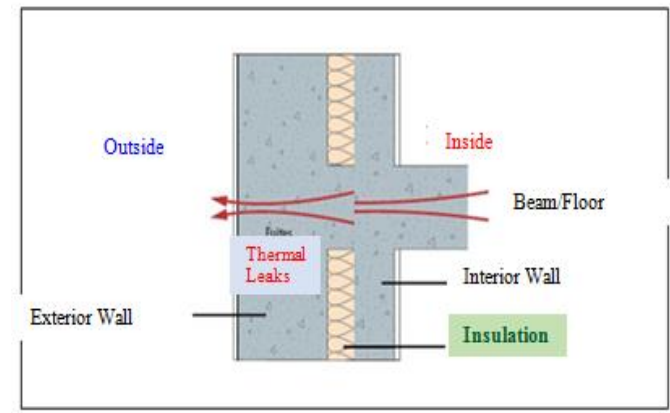

1. Distributed insulation

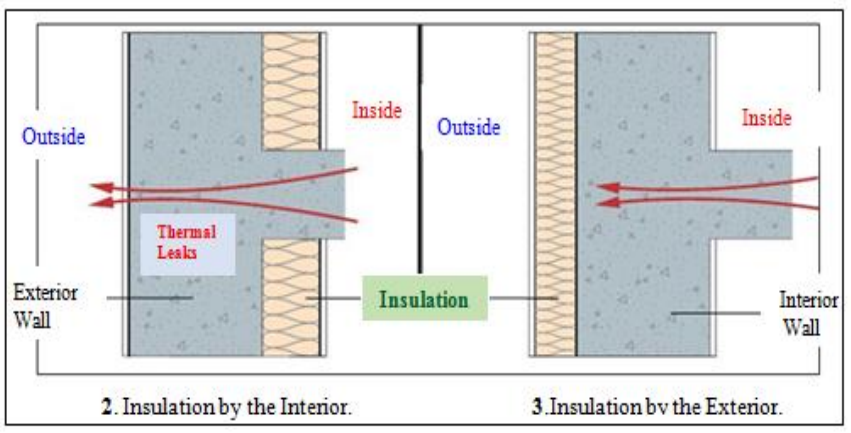

Figure 4. Insulation type of exterior walls

Table 1. Environmental indicators assessed

\begin{tabular}{cc}
\hline Environmental Indicator & Unit \\
\hline Greenhouse effect & $\mathrm{t} \mathrm{CO}_{2} \mathrm{eq}$. \\
Acidification & $\mathrm{kg} \mathrm{SO}_{2} \mathrm{eq}$. \\
Cumulative Energy Demand & $\mathrm{GJ}$ \\
Water used & $\mathrm{m}^{3}$ \\
Inert waste produced & $\mathrm{Tons}$ \\
Exhaustion of ambiotic resources & $\mathrm{kg} \mathrm{E}-15$ \\
Eutrophication & $\mathrm{kg} \mathrm{PO} 4 \mathrm{eq}$. \\
Ozone production photochemical & $\mathrm{kg} \mathrm{ethylene} \mathrm{eq.}$ \\
Aquatic ecotoxicity & $\mathrm{m}^{3}$ \\
Radioactive waste & $\mathrm{dm}^{3}$ \\
Human toxicity & $\mathrm{kg}$ \\
Odor & $\mathrm{m}^{3}$ air \\
\hline
\end{tabular}

\subsection{The simulation reasons}

This work involves modeling an office building in order to identify the optimal insulating materials (ecological materials, recycled materials, etc.), that enter into its envelope, as well as providing answers to the various techniques used to implement insulation. For this purpose, a functional unit was selected which is $1.00 \mathrm{~m}^{2}$ of landscaped office area (Figure 5); it is the best assessment and comparison unit. Also, ISO 14044 defines the Functional Unit as "Quantified performance of a product system, intended to be used as a reference unit in a LCA". The FU will be used to weight and introduce the results of a LCA on a common basis. The FU will make it possible to compare analyses and make choices.

This unit includes the elements of the concrete structure, the envelope materials, the interior partitions, the coatings and paints, the carpentry and the type of glazing (single or double glazing), as well as the elements of the exterior layout (water space, vegetation, etc.) that affect the energy balance and the environmental impact. 
It also includes energy consumption, solar gains and occupancy rates into the office.

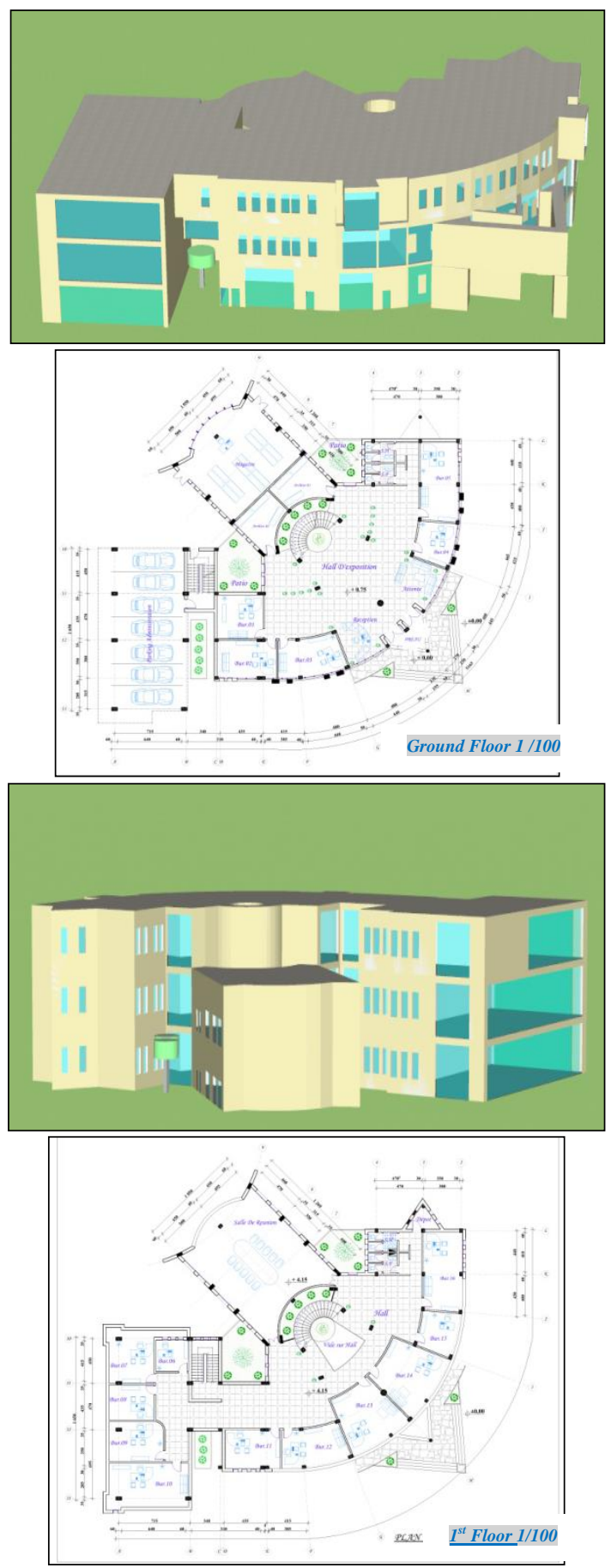

Figure 5. Graphic entry, and thermal zones of the building

\subsubsection{Analysis of insulation type}

This first level of simulation consists in studying the building in its initial state with all the technical solutions and the elements and treatments carried out (double wall, single glazing bays, structural and energy systems, etc.).

It involves modifying the insulation of the building envelope without changing the initial composition of the walls (extern wall $15 \mathrm{~cm} /$ Insulation/ Intern wall $10 \mathrm{~cm}$ ).

Two additional insulations were considered due to their outstanding thermal and environmental characteristics. The Expanded Polystyrene (synthetic origin, widely used in the construction sector and very available on the national market with different thickness and very accessible unit prices.), and
Cellulose Wadding (chosen for its outstanding technical, insulating and environmental characteristics, it is a material from recycling and $100 \%$ recyclable).

\subsubsection{Analysis of insulation techniques}

In this second, it will be necessary to define the best systems for isolating the building envelope.

Three 03 techniques for the installation of insulation are then considered, and they are defined according to ministerial order approving the Regulatory Technical Document DTRC3-T [26], of the Algerian thermal regulation of the building, existing:

a. Distributed Insulation where it is placed between the two walls of the envelope.

b. Interior Insulation, where the insulation is placed adjacent to the interior space.

c.Exterior Insulation, where the insulation is placed in direct contact with the outside environment.

\subsection{Occupancy and use scenarios}

The main energy simulation conditions common to all building envelope configurations (types and techniques of insulation) are [27]:

1. Constant Temperature of $20^{\circ} \mathrm{C}$

2. Heating Scenario: $20^{\circ} \mathrm{C}$ (and stop at night).

3. Scenario of Air Conditioning: $25^{\circ} \mathrm{C}$ (with stop at night).

4. Dissipated power scenario: $4100 \mathrm{~W}$

5. Occupancy of offices is $100 \%$ from $08.00 \mathrm{AM}$ to $17.00 \mathrm{PM}$, and $00 \%$ the rest of the time.

Also, the data required for the life cycle analysis of the building are structured into five main themes:

1. Building materials.

2. Energy.

3. Water.

4. Waste.

5. User transport

The conditions for the LCA environmental study of the building are then defined as follows:

a) Life for the analysis of the building is 80 years.

b) The life of the equipment is 20 years

c) Carpentry is 30 years.

d) 10 years for coatings.

Also, a gas heating system is considered, and an electric air conditioning.

\section{RESULTS AND DISCUSSIONS}

By the thermal, technical and insulating characteristics of the materials (Table 2), their respective environmental balances (Table 3), a first classification is established.

Cellulose Wadding present a [28]: better thermal conductivity $(\lambda) 0.042 \mathrm{~W} / \mathrm{m} . \mathrm{K}$, specific heat $1900 \mathrm{~kJ} / \mathrm{kg} . \mathrm{K}$ and especially and a very interesting phase shift time of $12 \mathrm{~h}$ (Table 2).

Produced from the recycling of paper and cardboard, cellulose wadding, an ecological material, presents a positive environmental record.

It promotes excellent summer comfort, with a reduced amount of grey energy used $50 \mathrm{kwh} / \mathrm{m}^{3}$, without any greenhouse effect and especially through its treatment at the end of life (100\% recyclable) (Table 3$)$.

The dynamic thermal simulation DTS has made it possible 
to define all the energy requirements (energy for heating, for air conditioning, and lighting, and the water used...) to ensure the comfort of the users, whatever the composition of the wall studied (Table 4). They illustrate very remarkable differences in energy requirements, and allow a first classification of the different compositions of the wall.

The thermal criterion, and whatever variant is studied, opts for the use of Cellulose Wadding in the composition of the external wall. It has the lowest energy requirements relative to other insulating materials. In the second row we find Expanded Polystyrene, followed by the air blade (Table 5).

The environment impact is a result of the energy consumption rate and the degree of thermal performance. It's demonstrated by this study Life Cycle Analysis of the building (Table 6). The results obtained show that the 'Cellulose Wadding insulated Wall' has less impact on the environment than the 'Expanded Polystyrene insulated Wall' or the conventional wall insulated with an air blade, whatever the indicator is considered, and this record in proportions (Table 6). It can also be noted that the most important impact are: consumption of resources, cumulative energy demand, and water used followed by the eutrophication, and acidification, (Figures 8, 9).

Consequently, comparing the different phases of the building life cycle, the use phase is the one with the highest impact (Figures 7, 10).

Also, the construction phase (a shorter duration compared to the life cycle of the building) with impacts mainly in: acidification, cumulative demand for energy, water used, production of photochemical ozone, and release inert waste and odors (Tables 8, 9).

Table 2. Insulation technical characteristics

\begin{tabular}{ccccccc}
\hline Cnaracteristics & \multicolumn{5}{c}{ Insulation Technical Characteristics } \\
\cline { 2 - 7 } & $\begin{array}{c}\text { Thermal } \\
\text { conductivity } \\
\lambda(\mathrm{W} / \mathrm{m} . \mathrm{K})\end{array}$ & $\begin{array}{c}\text { Density } \\
\left(\mathrm{kg} / \mathrm{m}^{3}\right)\end{array}$ & $\begin{array}{c}\text { Specific } \\
\text { heat } \\
(\mathrm{kJ} / \mathrm{kg} . \mathrm{K})\end{array}$ & $\begin{array}{c}\text { Resistance } \\
\text { vapour } \\
\text { diffusion }(\mathrm{m})\end{array}$ & $\begin{array}{c}\text { Time of } \\
\text { Phase Shift } \\
\text { Hour }\end{array}$ & $\begin{array}{c}\text { Hygroscopic } \\
\text { capacity }\end{array}$ \\
\hline $\begin{array}{c}\text { Air blade } \\
\text { Expanded Polystyrene }\end{array}$ & 0.026 & 1 & 1000 & 0 & 03 & No \\
Cellulose Wadding & 0.032 & 10 & 1450 & 20 & 04 & No \\
\hline
\end{tabular}

Table 3. Environmental characteristics of insulation

\begin{tabular}{cccccc} 
Characteristics & \multicolumn{4}{c}{ Environmental Assessment } \\
\cline { 2 - 6 } Insulation & $\begin{array}{c}\text { Grey energy } \\
\text { used }\left(\mathrm{kWh} / \mathrm{m}^{3}\right)\end{array}$ & $\begin{array}{c}\text { Greenhouse } \\
\text { effect } \\
\left(\mathrm{kgCO}_{2} / \mathrm{UF}\right)\end{array}$ & $\begin{array}{c}\text { End } \\
\text { of-life } \\
\text { treatment }\end{array}$ & $\begin{array}{c}\text { Nature } \\
\text { of the } \\
\text { insulation }\end{array}$ & $\begin{array}{c}\text { Comfort of } \\
\text { Summer } \\
\text { Obtained }\end{array}$ \\
\hline $\begin{array}{c}\text { Expanded Polystyrene } \\
\text { Cellulose Wadding }\end{array}$ & 450 & 10 & $100 \%$ in Landfill & Synthetic & $9 / 20$ \\
10 & -10 & $100 \%$ recyclable & From Recycling & $18 / 20$ \\
\hline
\end{tabular}

Table 4. Energy requirements of wall composition

\begin{tabular}{|c|c|c|c|c|c|c|c|}
\hline \multirow{2}{*}{ Energy requirements } & \multicolumn{3}{|c|}{ Distributed Insulation } & \multicolumn{2}{|c|}{ Insulation by Exterior } & \multicolumn{2}{|c|}{ Insulation by Interior } \\
\hline & $\begin{array}{c}\text { Air blade } \\
1\end{array}$ & $\begin{array}{c}\text { Polystyrene } \\
2\end{array}$ & $\begin{array}{c}\text { Cellulose } \\
\text { Wadding } 3\end{array}$ & $\begin{array}{c}\text { Polystyrene } \\
4\end{array}$ & $\begin{array}{c}\text { Cellulose } \\
\text { Wadding } 5\end{array}$ & $\begin{array}{c}\text { Polystyrene } \\
6\end{array}$ & $\begin{array}{l}\text { Cellulose } \\
\text { Wadding } 7\end{array}$ \\
\hline Energy Heating & $10,082.00$ & 888.00 & $9,327.00$ & $9,327.00$ & $8,694.00$ & $9,344.00$ & $8,628.00$ \\
\hline Energy Heating $/ \mathrm{m}^{2} \quad \mathrm{Kwh} / \mathrm{m}^{2}$ & 19.00 & 9.00 & 18.00 & 18.00 & 17.00 & 18.00 & 17.00 \\
\hline Energy Air Condit & $30,772.00$ & $20,350.00$ & $29,567.00$ & $29,567.00$ & $28,774.00$ & $29,384.00$ & $28,851.00$ \\
\hline Energy Air Condit $/ \mathrm{m}^{2} \mathrm{Kwh} / \mathrm{m}^{2}$ & 59.00 & 213.00 & 57.00 & 57.00 & 55.00 & 56.00 & 55.00 \\
\hline
\end{tabular}

Table 5. Environmental impacts of wall composition

\begin{tabular}{|c|c|c|c|c|c|c|c|}
\hline \multirow{2}{*}{ Environmental Impact } & \multicolumn{3}{|c|}{ Distributed Insulation } & \multicolumn{2}{|c|}{ Insulation by Exterior } & \multicolumn{2}{|c|}{ Insulation by Interior } \\
\hline & Air b.1 & EPS2 & CWD3 & EPS4 & CWD5 & EPS6 & CWD7 \\
\hline Greenhouse effect (t $\mathrm{CO}_{2}$ eq.) & 797.21 & 753.98 & 751.46 & 586.65 & 533.69 & 755.70 & 747.99 \\
\hline Acidification ( $\mathrm{kg} \mathrm{SO}_{2}$ eq.) & $2,619.51$ & $2,486.56$ & $2,515.38$ & $2,324.18$ & $2,125.00$ & $2,492.59$ & $2,504.99$ \\
\hline $\begin{array}{l}\text { Cumulative Energy } \\
\text { Demand (GJ) }\end{array}$ & $17,920.88$ & $16,927.74$ & $16,980.94$ & $21,585.12$ & $19,808.80$ & $16,955.46$ & $16,880.20$ \\
\hline Water Used $\left(\mathrm{m}^{3}\right)$ & $35,821.18$ & $35,133.86$ & $35,379.54$ & $37,519.84$ & $35,975.52$ & $35,162.42$ & $35,319.37$ \\
\hline Inert Waste Produced $(\mathrm{t})$ & 476.58 & 470.60 & 471.93 & 453.43 & 447.21 & 470.85 & 471.46 \\
\hline $\begin{array}{c}\text { Exhaustion of } \\
\text { Abiotic Resources (kg E-15) }\end{array}$ & 6.22 & 5.88 & 5.93 & 9.93 & 8.56 & 5.88 & 5.87 \\
\hline Eutrophication ( $\mathrm{kg} \mathrm{PO}_{4}$ eq.) & 854.80 & 843.15 & 844.98 & 820.81 & $2,104.83$ & 843.66 & 844.06 \\
\hline $\begin{array}{l}\text { Ozone Production } \\
\text { Photochemical (kg ethylene eq.) }\end{array}$ & $1,390.97$ & $1,324.13$ & $1,331.02$ & $1,173.57$ & $1,074.94$ & $1,327.00$ & $1,325.74$ \\
\hline Aquatic Ecotoxicity $\left(\mathrm{m}^{3}\right)$ & $\begin{array}{l}14,916 \\
261.98\end{array}$ & $\begin{array}{l}14,066 \\
767.68\end{array}$ & $\begin{array}{l}14308 \\
094.30\end{array}$ & $\begin{array}{l}13,908 \\
914.16\end{array}$ & $\begin{array}{l}12312 \\
913.35\end{array}$ & $\begin{array}{l}14105 \\
868.40\end{array}$ & $\begin{array}{l}14,241 \\
240.52\end{array}$ \\
\hline Radioactive Waste $\left(\mathrm{dm}^{3}\right)$ & 23.18 & 22.03 & 22.43 & 44.35 & 38.26 & 22.04 & 22.28 \\
\hline Human Toxicity (kg) & $3,413.08$ & $3,249.66$ & $3,283.02$ & $3,007.39$ & 2,771.97 & $3,257.05$ & $3,270.15$ \\
\hline Odor ( $\mathrm{m}^{3}$ air) & $8,570.37$ & $8,060.43$ & $7,894.46$ & $4,845.60$ & $\mathbf{4 , 3 7 8 . 5 0}$ & $8,077.86$ & $7,852.38$ \\
\hline
\end{tabular}


Table 6. Environmental Impacts by Life Cycle Phase. Wall insulated from outside with Expanded Polystyrene

\begin{tabular}{|c|c|c|c|c|c|}
\hline Impact & Construction & Use & Renovation & Demolition & Total \\
\hline Greenhouse Effect (t $\mathrm{CO}_{2}$ eq.) & 83.37 & 502.47 & -0.96 & 1.76 & 586.65 \\
\hline Acidification (kg SO 2 eq.) & 346.98 & $1,956.59$ & 0.48 & 20.14 & $2,324.18$ \\
\hline Cumulative Energy Demand (GJ) & $1,002.54$ & $20,539.14$ & 14.63 & 28.81 & $21,585.12$ \\
\hline Water Used $\left(\mathrm{m}^{3}\right)$ & 562.84 & $36,941.85$ & 1.64 & 13.51 & $37,519.84$ \\
\hline Inert Waste Produced (t) & 24.33 & 85.77 & 0.08 & 343.25 & 453.43 \\
\hline Exhaustion of Abiotic Resources (kg E-15) & 0.29 & 9.63 & 0 & 0.01 & 9.93 \\
\hline Eutrophication ( $\mathrm{kg} \mathrm{PO}_{4}$ eq.) & 37.92 & 779.66 & 0.08 & 3.15 & 820.81 \\
\hline $\begin{array}{c}\text { Photochemical Ozone } \\
\text { Production (kg ethylene eq.) }\end{array}$ & 218.29 & 933.02 & 0.37 & 21.89 & $1,173.57$ \\
\hline Aquatic Eco-Toxicity $\left(\mathrm{m}^{3}\right)$ & $837,408.61$ & $\begin{array}{l}13,012 \\
744.12\end{array}$ & 899.69 & $57,861.74$ & $\begin{array}{l}13,908 \\
914.16\end{array}$ \\
\hline Radioactive Waste $\left(\mathrm{dm}^{3}\right)$ & 1.99 & 42.24 & 0.02 & 0.11 & 44.35 \\
\hline Human Toxicity $(\mathrm{kg})$ & 494.33 & $2,486.80$ & 2.05 & 24.21 & $3,007.39$ \\
\hline Odor $\left(\mathrm{Mm}^{3}\right.$ air $)$ & 315.49 & $4,528.09$ & 0.03 & 1.98 & $4,845.60$ \\
\hline
\end{tabular}

Table 7. Environmental Impacts by Life Cycle Phase. Wall insulated from outside with Cellulose Wadding

\begin{tabular}{|c|c|c|c|c|c|}
\hline Impact & Construction & Use & Renovation & Demolition & Total \\
\hline Greenhouse effect ( $\mathrm{CO}_{2}$ eq.) & 83.29 & 449.60 & -0.96 & 1.76 & 533.69 \\
\hline Acidification (kg SO 2 eq.) & 345.99 & $1,758.43$ & 0.48 & 20.10 & 2,125 \\
\hline Cumulative Energy Demand (GJ) & 999.98 & $18,765.42$ & 14.63 & 28.77 & $19,808.80$ \\
\hline Water used $\left(\mathrm{m}^{3}\right)$ & 562.50 & $35,397.89$ & 1.64 & 13.49 & $35,975.52$ \\
\hline Inert waste produced $(\mathrm{t})$ & 24.29 & 80.16 & 0.08 & 342.68 & 447.21 \\
\hline Exhaustion of abiotic resources (kg E-15) & 0.29 & 8.26 & 0 & 0.01 & 8.56 \\
\hline Eutrophication (kg PO4 eq.) & 37.83 & $2,063.78$ & 0.08 & 3.14 & $2,104.83$ \\
\hline $\begin{array}{l}\text { Photochemical ozone } \\
\text { production (kg ethylene eq.) }\end{array}$ & 217.68 & 835.04 & 0.37 & 21.85 & $1,074.94$ \\
\hline Aquatic eco-toxicity $\left(\mathrm{m}^{3}\right)$ & $834,117.06$ & $11,420,130.83$ & 899.69 & $57,765.76$ & $12,312,913.35$ \\
\hline Radioactive waste $\left(\mathrm{dm}^{3}\right)$ & 1.99 & 36.15 & 0.02 & 0.11 & 38.26 \\
\hline Human toxicity (kg) & 492.97 & $2,252.78$ & 2.05 & 24.17 & $2,771.97$ \\
\hline Odor $\left(\mathrm{Mm}^{3}\right.$ air $)$ & 314.82 & $4,061.67$ & 0.03 & 1.98 & $4,378.50$ \\
\hline
\end{tabular}

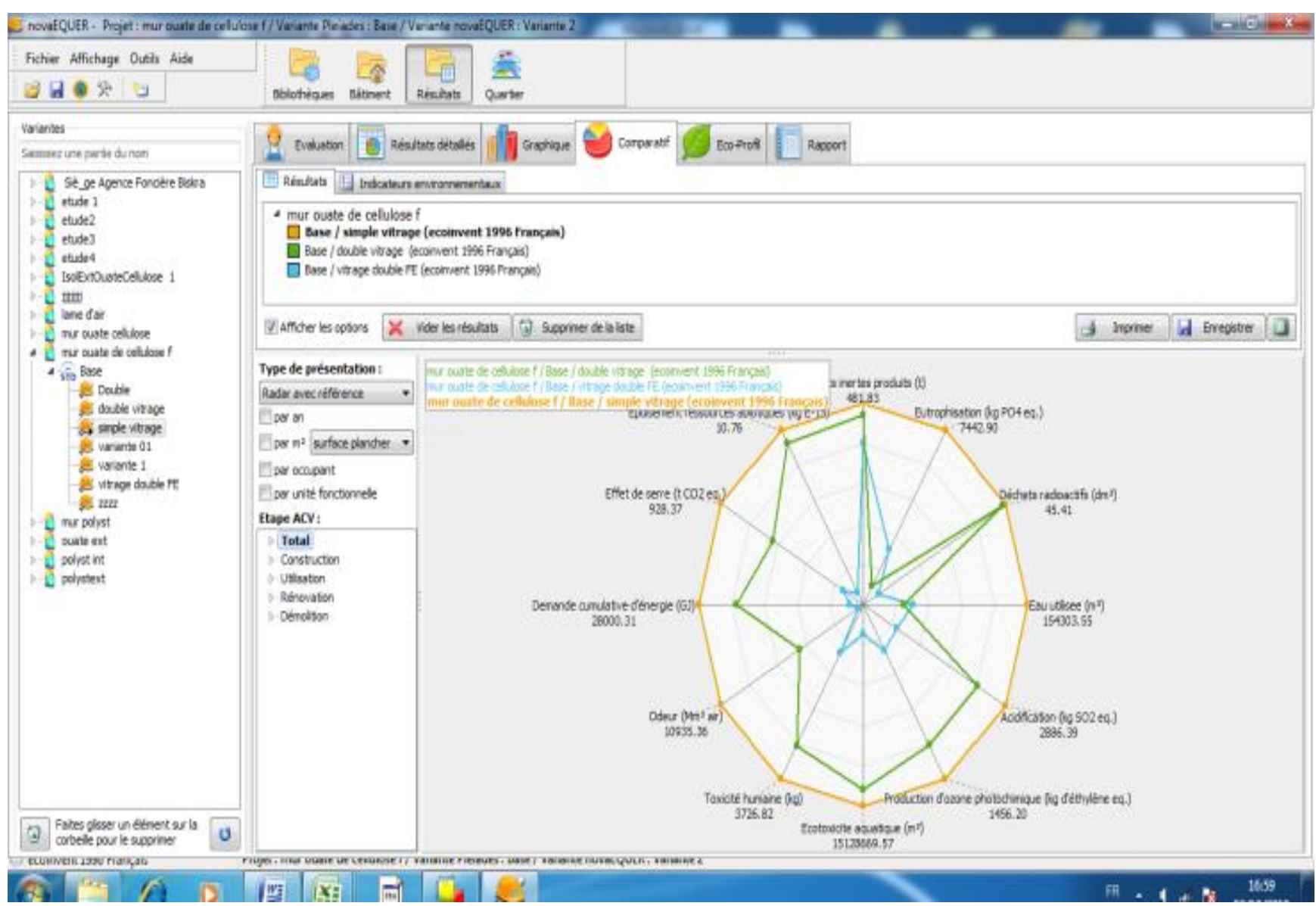

Figure 6. Radar Diagram of different insulation of exterior walls 


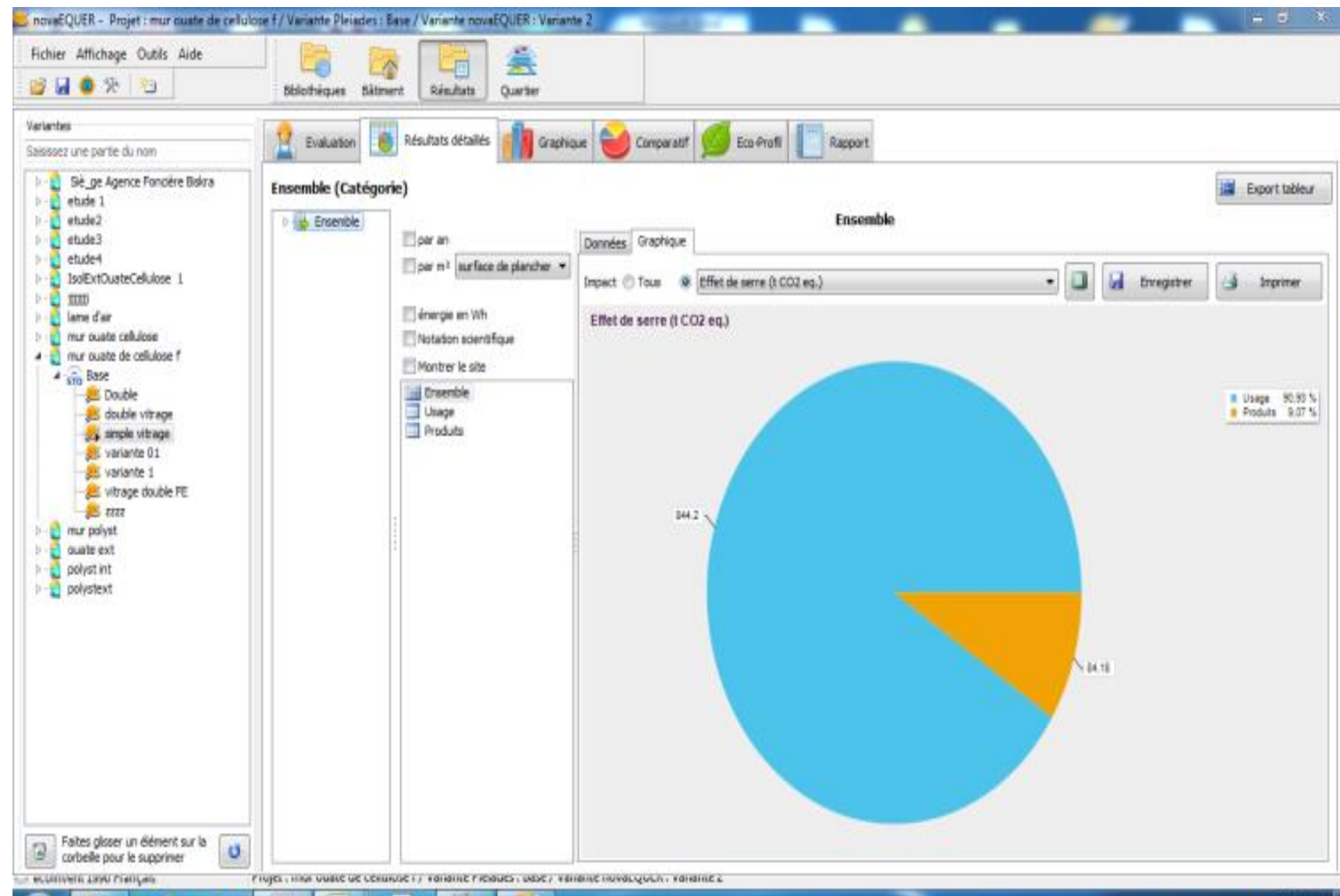

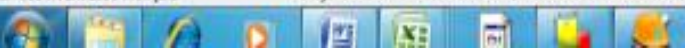

Figure 7. Greenhouse effect at the building use

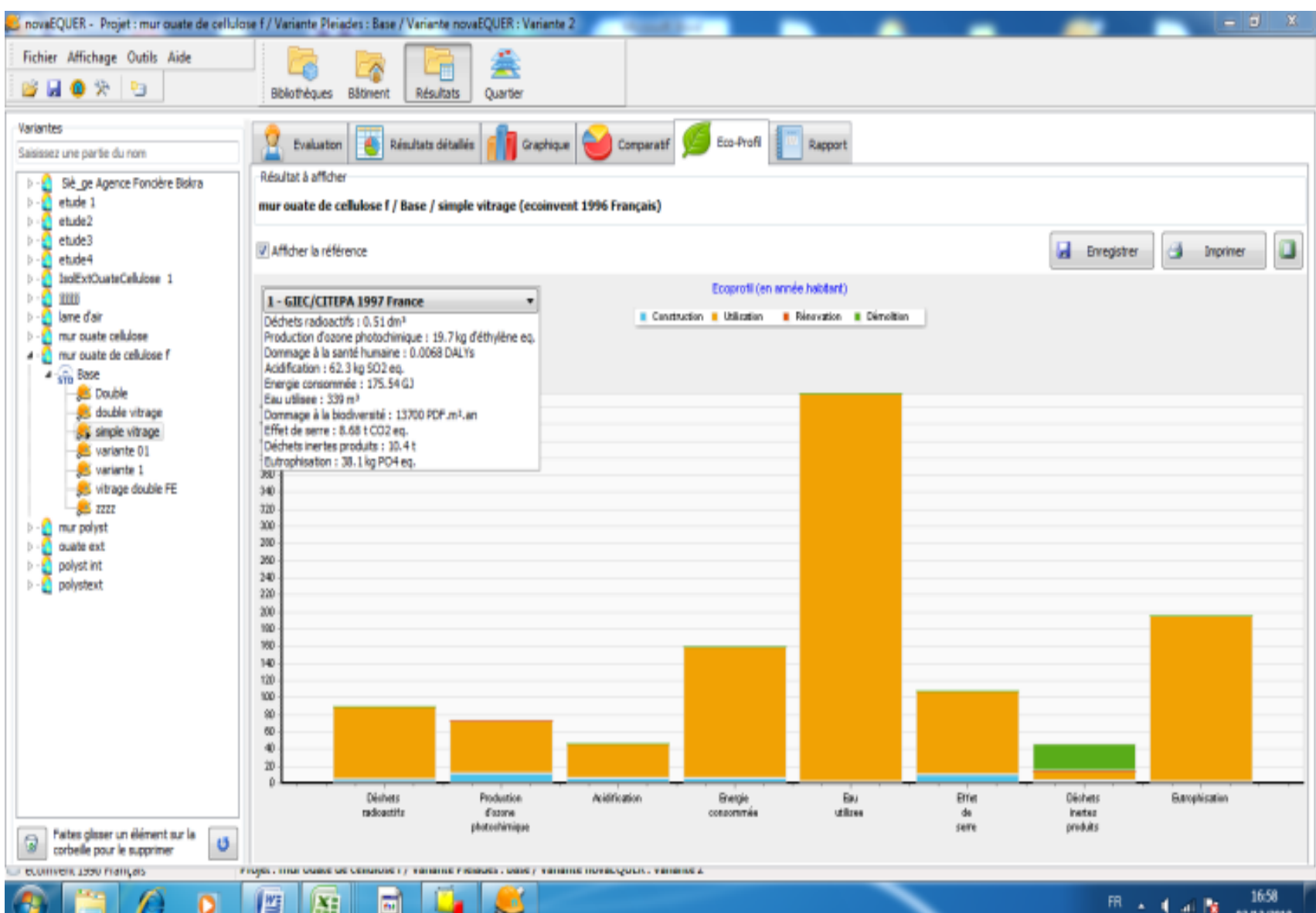

Figure 8. Ecoprofil of Impacts by Life Cycle Phase of building 


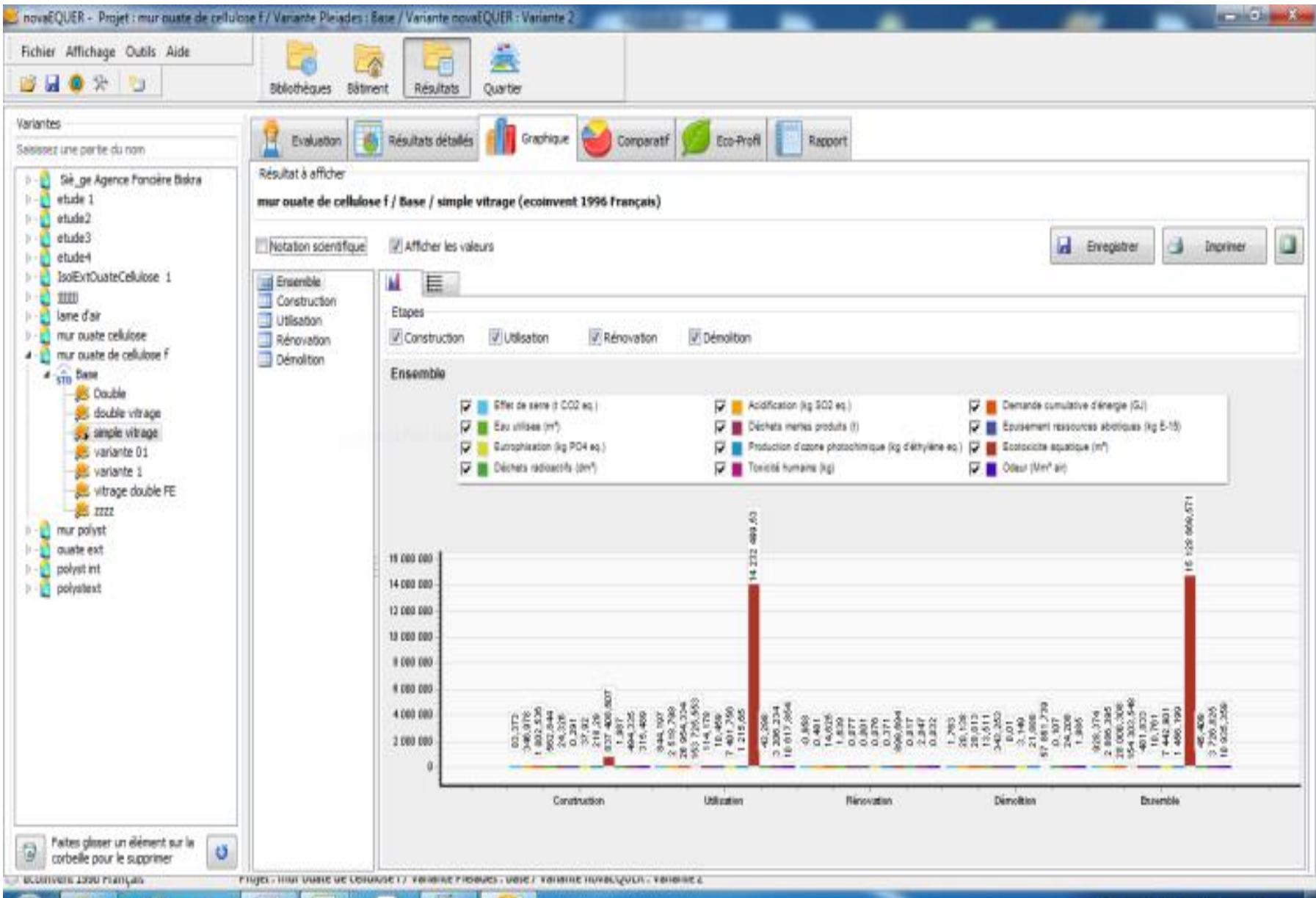

A

Figure 9. Numerical graphic of Impacts by Life Cycle Phase of building

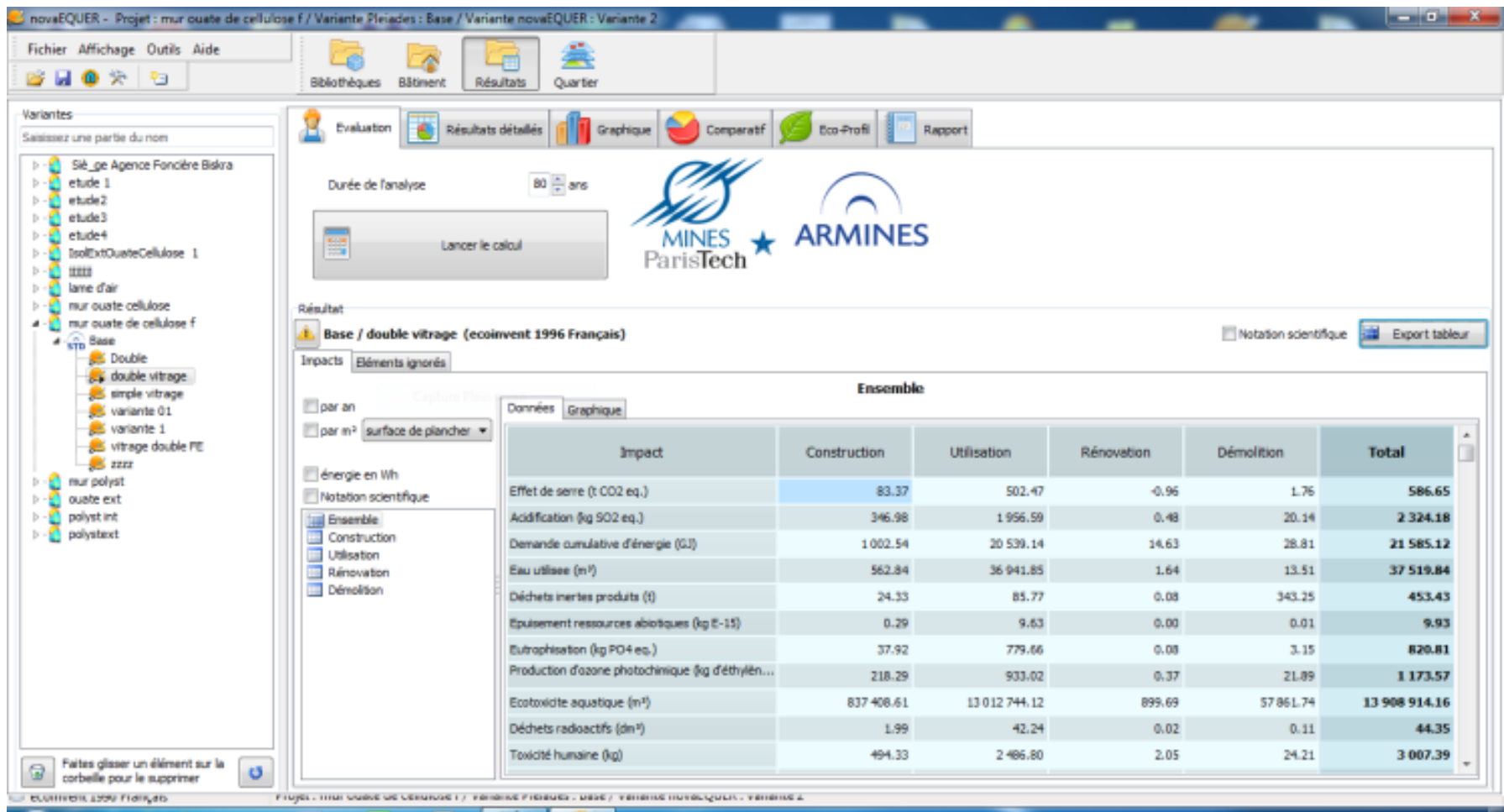

Figure 10. Environmental Impacts by Life Cycle Phase of building 
Table 8. Environmental Impacts by Life Cycle Phase of building

\begin{tabular}{cccccc}
\hline Impact & Construction & Use & Renovation & Demolition & Total \\
\hline Greenhouse Effect (t CO 2 eq.) & 83.37 & 502.47 & -0.96 & 1.76 & 586.65 \\
Acidification (kg SO eq.) & 346.98 & $1,956.59$ & 0.48 & 20.14 & $2,324.18$ \\
Cumulative Energy Demand (GJ) & $1,002.54$ & $20,539.14$ & 14.63 & 28.81 & $21,585.12$ \\
Water Used (m ${ }^{3}$ ) & 562.84 & $36,941.85$ & 1.64 & 13.51 & $37,519.84$ \\
Inert Waste Produced (t) & 24.33 & 85.77 & 0.08 & 343.25 & 453.43 \\
Exhaustion of abiotic Resources (kg E-15) & 0.29 & 9.63 & 0 & 0.01 & 9.93 \\
Eutrophication (kg PO4 eq.) & 37.92 & 779.66 & 0.08 & 3.15 & 820.81 \\
Photochemical Ozone & 218.29 & 933.02 & 0.37 & 21.89 & $1,173.57$ \\
production (kg ethylene eq.) & $837,408.61$ & $13,012,744.12$ & 899.69 & $57,861.74$ & $13,908,914.16$ \\
Aquatic Eco-Toxicity (m) & 1.99 & 42.24 & 0.02 & 0.11 & 44.35 \\
Radioactive Waste (dm ${ }^{3}$ ) & 494.33 & $2,486.80$ & 2.05 & 24.21 & $3,007.39$ \\
Human Toxicity (kg) & 315.49 & $4,528.09$ & 0.03 & 1.98 & $4,845.60$ \\
Odor (Mm ${ }^{3}$ air) & & & &
\end{tabular}

Table 9. Environmental Impacts at the Use Phase of building

\begin{tabular}{|c|c|c|c|c|c|c|c|}
\hline Impact & Heating & $\begin{array}{c}\text { Sanitary Hot } \\
\text { Water }\end{array}$ & Water & $\begin{array}{c}\text { Specific } \\
\text { Electricity }\end{array}$ & $\begin{array}{c}\text { Air } \\
\text { Conditioning }\end{array}$ & Transport & Total \\
\hline $\begin{array}{l}\text { Greenhouse effect } \\
\quad(\mathrm{t} \mathrm{CO} 2 \text { eq. })\end{array}$ & 18.16 & 52.15 & 12.09 & 140.23 & 264.39 & 15.44 & 502.47 \\
\hline Acidification (kg SO 2 eq.) & 21.54 & 61.84 & 76.93 & 595.32 & $1,094.87$ & 106.08 & $1,956.59$ \\
\hline $\begin{array}{l}\text { Cumulative Energy } \\
\text { Demand (GJ) }\end{array}$ & 337.10 & 967.92 & 387.14 & $11,577.70$ & $7,015.31$ & 253.97 & $20,539.14$ \\
\hline Water used $\left(\mathrm{m}^{3}\right)$ & 22.42 & 64.36 & $24,282.19$ & $5,965.46$ & $6,483.52$ & 123.90 & $36,941.85$ \\
\hline Inert waste produced $(\mathrm{t})$ & 1.48 & 4.24 & 2.07 & 27.96 & 45.20 & 4.83 & 85.77 \\
\hline $\begin{array}{l}\text { Exhaustion of abiotic } \\
\text { Resources (kg E-15) }\end{array}$ & 0.09 & 0.27 & 0.07 & 6.39 & 2.68 & 0.12 & 9.63 \\
\hline $\begin{array}{l}\text { Eutrophication }\left(\mathrm{kg} \mathrm{PO}_{4} \mathrm{eq}\right) \\
\text { Photochemical ozone }\end{array}$ & 2.56 & 7.36 & 620.63 & 48.80 & 90.40 & 9.91 & 779.66 \\
\hline $\begin{array}{l}\text { Production (kg ethylene } \\
\text { eq) }\end{array}$ & 18.23 & 52.35 & 21.58 & 264.34 & 489.72 & 86.79 & 933.02 \\
\hline Aquatic eco-toxicity $\left(\mathrm{m}^{3}\right)$ & $\begin{array}{c}80,855.3 \\
2\end{array}$ & $232,164.51$ & $\begin{array}{c}312,562.3 \\
3\end{array}$ & $4,401,319.53$ & $7,474,072.85$ & $\begin{array}{c}511,769.6 \\
0\end{array}$ & $\begin{array}{c}13,012,744.1 \\
2\end{array}$ \\
\hline Radioactive waste $\left(\mathrm{dm}^{3}\right)$ & 0.11 & 0.33 & 0.87 & 29.72 & 10.95 & 0.26 & 42.24 \\
\hline Human toxicity (kg) & 28.93 & 83.06 & 102.63 & 729.41 & $1,334.43$ & 208.33 & $2,486.80$ \\
\hline Odor $\left(\mathrm{Mm}^{3}\right.$ air $)$ & 344.67 & 989.67 & 30.97 & $1,089.41$ & $2,050.89$ & 22.50 & $4,528.09$ \\
\hline
\end{tabular}

Other, the renovation (Table 7) phase does not generate any impact, and the end-of-life phase has impacts on inert waste (Table 9).

The results of this study (Figure 6, radar diagrams) show that the cellulose wadding wall is the most interesting, from the point of view of energy and environmental optimization, relative to other wall.

According to the LCA life cycle analysis, the energy criterion associated with the environmental balance is favourable for the benefit of external insulation (Table 6).

This external insulation is easy to implement, very fast, eliminates thermal bridges and benefits from the thermal inertia of the walls.

The interior insulation has disadvantages: It favour's thermal bridges and condensation points, deprives the walls of thermal inertia, and reduces interior space, and also additional energy consumption.

Also, distributed insulation, at a new building, ensures a level of comfort but with very high energy consumption over the entire life cycle of the building (Figure 6).

\section{CONCLUSIONS}

The environmental assessment method used is Life Cycle Analysis LCA, in accordance with ISO 14040 to 14044 . It combines different building materials and assemblies within the building envelope, using the Eco-Invent database and based on the Life Cycle Analysis Software, connected to dynamic thermal simulation software. The results highlight the construction and operation stages as well as those that have an impact on the environment. Then, the results of this study, it can be seen that for all impacts, cellulose wadding is a more environmentally friendly material than other insulating materials. Expanded polystyrene gives very acceptable thermal results, but very impactful on the environment. Insulation techniques also play a very decisive role in the energy aspect, closely linked to the environmental impacts generated.

Exterior insulation is also the most effective and has less impact than distributed insulation. And the interior insulation has more energy disadvantages than thermal advantages. The comparison of different walls, the exterior insulation system, obtained the best environmental scores, being 30\% less than the interior insulation system and 50\% less than the distributed insulation system.

Therefore, the exterior insulation is the most efficient as it eliminates in particular the thermal bridges, and allows to benefit from the thermal inertia of the walls. Also, given that cellulose wadding, should be used more in construction as an ecological material resulting from recovery and recycling, and no longer as waste.

It would also be more interesting to opt for the technique of insulation from the outside insulation for more energy savings 
and less environmental impacts. It's the most efficient as it eliminates in particular the thermal bridges, and allows to benefit from the thermal inertia of the walls. The results of this research can be used as an inventory of strategies for a sustainable building, including energy retrofits. It is an ecological approach, which helps to fight earth warming, the reduction of greenhouse gas emissions, and the reduction of the environmental impact. Also, life cycle analysis LCA is a strategy, and a decision-making tool, to contribute to this heavy environmental issue resulting from poor building design. This work shows how LCA application is not only feasible, but recommended because it is a decision support tool and a basic element in the search for sustainability.

\section{REFERENCES}

[1] Brundtland (1987). Our Common Future, Brundtland Report, World Commission Book on Environment and Development, Oxford University Press. http://www.undocuments.net/ocf-ov.htm.

[2] ADEME. (2018). Climate, Air and Energy; Key Figures. 2018 Edition. Brochure réf.: 010354, ISSN électronique : 2556-532X, ISBN web: 979-10-297-1204-3.

[3] Thiers, S., Peuportier, B. (2011). Energy and Environmental assessment of two high energy performance residential buildings. Building and Environment, 51: 276-284 https://doi.org/10.1016/j.buildenv.2011.11.018

[4] Gámez-García, D.C., Saldaña-Márquez, H., GómezSoberón, J.M., Arredondo-Rea, S.P., Gómez-Soberón, M.C., Corral-Higuera, R. (2019). Environmental challenges in the residential sector: Life cycle assessment of Mexican social housing. Energies, 12(14): 2837. https://doi.org/10.3390/en12142837

[5] Dossche, C., Veerle, B., De Corte, W. (2017). Use of life cycle assessments in the construction sector: Critical review. Procedia Engineering, 71: 302-311. https://doi.org/10.1016/j.proeng.2017.01.338

[6] Gomes, R., Silvestre, J.D., de Brito, J. (2019). Environmental life cycle assessment of thermal insulation tiles for flat roofs. Materials, 12(16): 2595; https://doi.org/10.3390/ma12162595

[7] ISO, International Organization for Standardization (2006). ISO 14040, Life Cycle Analysis, Principles and Framework. ISO / TC207/SC5 Life Cycle Assessment.

[8] ISO, International Organization for Standardization (2006). ISO14044, Life Cycle Analysis, Requirements and Guidelines. ISO/TC207/SC5Life Cycle Assessment.

[9] Birgisdottir, H., Moncaster, A., Houlihan Wiberg, A., Chae, C., Yokoyama, K., Balouktsi, M., Seo, S., Oka, T., Lützkendorf, T., Malmqvist, T. (2017). IEA EBC annex 57 'evaluation of embodied energy and $\mathrm{CO}_{2 \mathrm{eq}}$ for building construction'. Energy and Buildings, 154: 72-80. https://doi.org/10.1016/j.enbuild.2017.08.030

[10] UNEP, SETAC. (2015). Guidance on Organizational Life Cycle Assessment. ISBN: 978-92-807-3453-9 https://www.lifecycleinitiative.org.

[11] Yovanna Elena Valencia-Barba, José Manuel GómezSoberón, María Consolación Gómez-Soberón, Fernando López-Gayarre. (2020). An epitome of building floor systems by means of LCA criteria. Sustainability, 12(13): 5442. https://doi.org/10.3390/su12135442

[12] Jolliet, O., Saade-Sbeih, M., Shaked, S., Jolliet, A.,
Crettaz, P. (2015). Environmental Life Cycle Assessment. $1^{\text {st }}$ Edition, CRC Press.

[13] Silvestre, J.D., Pargana, N., de Brito, J., Pinheiro, M.D. (2014). Environmental life cycle assessment from cradle to cradle of insulation cork boards. Conférence: Congresso Luso-Brasileiro de Materiais de Construção Sustentáveis (CLB-MCS 2014) Portugal. https://doi.org/10.13140/RG.2.1.2451.0483

[14] Dakhia, A. (2018). The life cycle analysis (LCA) of a sustainable building by studying the thermal insulation system: Case of an office building in the city of Biskra, Algeria. Courrier du Savoir, 26: 191-202. http://revues.univbiskra.dz/index.php/cds/article/view/3933.

[15] Pietrapertosa, F., Tancredi, M., Giordano, M., Cosmi, C., Salvia, M. (2020). How to prioritize energy efficiency intervention in municipal public buildings to decrease $\mathrm{CO}_{2}$ emissions? A case study from Italy. International Journal of Environmental Research and Public Health, 17(12): 4434. https://doi.org/10.3390/ijerph17124434

[16] Peuportier, B., Schalbart, P. (2019). Building life cycle assessment tools developed in France. IALCCE 2018 the Sixth International Symposium on Life-Cycle Civil Engineering, Oct 2018, Ghent, Belgium. hal-01982627.

[17] Gámez-García, D.C., Gómez-Soberón, J.M., CorralHiguera, R., Saldaña-Márquez, H., Gómez-Soberón, M.C., Arredondo-Rea, S.P. (2018). A cradle to handover life cycle assessment of external walls: Choice of materials and prognosis of elements. Sustainability, 10(8): 2748. https://doi.org/10.3390/su10082748

[18] EASE, European Project (Education of architects on solar energy and environment). (2010). LCA: the life cycle approach to Buildings. www.cep.ensmp.fr/ease/sustain main.html.

[19] Mazouz, S. (2014), Architectural Design Element: Conceptual Aspects. 5nd Edition, Office for University Publications, Algiers.

[20] Konya, A. (1984). Design Primer for Hot Climates/ Drawings by Charles Swanpeoel. Paperback Edition.

[21] COIMBA. (2011). Building Environmental Impact Knowledge: Development of Building Environmental Quality Assessment Tools by Life Cycle Analysis. Salmon N., Duclos L. et Fillit F.: NOBATEK / Peuportier B.et Herfray G.: Armines, CEP / Chevalier J., Schipu N., lasvaux S. et Lebert A.: CSTB/ Jean-L. Sénégas et R. Mikolase: Izuba energy. https://www.construction21.org/france/tags/YsOidGltZ W50.

[22] Al-Hamoud, M.S. (2005). Performance characteristics and practical applications of common building thermal insulation materials. Building and Environment, 40(3): 353-366.

http://dx.doi.org/10.1016/j.buildenv.2004.05.013

[23] Munaretto, F. (2014). Study of the influence of thermal inertia on the energy performance of buildings. $\mathrm{PhD}$ Thesis, Paris Tech., France.

[24] Bodart, M., Evrard, A., International PLEA Organisation. (2011). Architecture and sustainable development. Conference Proceedings of the 27th International Conference on Passive and Low Energy Architecture, Louvain-la-Neuve, Belgium.

[25] INIES data base. French national baseline on impacts environmental and health products, equipment and 
services for evaluating the performance of works. [on ligne] http://www.base-inies.fr/Inies/default.aspx.

[26] Ministry of Habitat. (2015). Regulatory Technical Document (D.T.R. C3-2), «Thermal regulation of residential buildings Rules for calculating heat losses», Paper1, CNERIB National Centre for Integrated Study and Building Research, Algiers. http//www.mnh.gov.

[27] Dakhia, A. (2019). Life cycle analysis as a strategy for the development of a sustainable building in arid environments with a hot and dry climate. Case of the city of Biskra, Algeria. PhD thesis, Biskra University, Algeria. http//www.univ.Biskra.dz/thesis.univ-Biskra.dz.

[28] AFNOR, French Standards Association. (2004). NF P01010, Environmental Quality of Construction Products, Environmental and Health Declaration of Construction Products

https://shop.snv.ch/Standard/Constructionmaterials/NF-P01-010.html.

\section{NOMENCLATURE}

L.C.A.

DTS

HVAC

DTR

$\mathrm{Sd}$

$\mathrm{d}$

$\lambda$

$\mathrm{cp}$

$\mathrm{Ge}$

G E use
Life cycle assessment/Life cycle analysis Dynamic thermal simulation Heating, ventilation, air conditioning Regulatory technical document.

Resistance to water vapour diffusion,m Densité, $\mathrm{kg} / \mathrm{m}^{3}$

Thermal conductivity, W. $\mathrm{m}^{-1} \cdot \mathrm{K}^{-1}$ Specific heat, $\mathrm{j}$

Greenhouse effect, $\mathrm{kg} / \mathrm{CO}_{2} / \mathrm{UF}$

Grey energy use, $\mathrm{kwh} / \mathrm{m}^{3}$ 